\title{
HEAVYWEIGHTS \\ THE IMPACT OF LARGE BUSINESSES ON PRODUCTIVITY GROWTH
}

\author{
OLIVER FALCK
}

CESIFO WORKING PAPER NO. 2135

CATEGORY 9: INDUSTRIAL ORGANISATION

OCTOBER 2007

\footnotetext{
An electronic version of the paper may be downloaded

- from the SSRN website:

- from the RePEc website:

- from the CESifo website:

www.SSRN.com

Www.RePEc.org

www.CESifo-group.org/wp
} 


\title{
HEAVYWEIGHTS THE IMPACT OF LARGE BUSINESSES ON PRODUCTIVITY GROWTH
}

\begin{abstract}
The idea of an industrial policy that promotes large businesses-heavyweights - as the best way to compete in a globalized world has become, again, en vogue among European politicians. The only apparent controversy about the idea revolves around whether it is better to promote national champions or, instead, European champions. Empirical evidence on the issue is rare and contradictory. A uniquely rich industry-level dataset for Germany is used in this paper to test whether large business size in an industry fosters growth in terms of total factor productivity (TFP). The results suggest that the overall effects of firm size on TFP growth are negative.
\end{abstract}

JEL Code: L11, L16, O33, O40.

Keywords: firm size, productivity growth, total factor productivity, innovation.

\author{
Oliver Falck \\ Ifo Institute for Economic Research \\ at the University of Munich \\ and CESifo \\ Poschingerstr. 5 \\ 81679 Munich (Germany) \\ falck@ifo.de
}

This version: August 2007 


\section{Introduction}

In boxing, the heavyweight class has been variously defined over time. In the 19th century, for example, many heavyweight champions weighed around 170 pounds. In 1920, the minimum weight for a heavyweight was set at 175 pounds. Today, for most boxing organizations, the minimum weight for a heavyweight is 201 pounds.

More or less the same is true for industrial heavyweights. The 20th century gave birth to the first traditional industrial heavyweights (for an overview, see Heblich, 2007). During this century, firms grew larger due to the realization of economies of scale and scope, a situation that led to industries characterized by mass production and a highly vertical form of integration. The economic historian Gerschenkron (1962) argues that in such a situation relatively backward economies, such as Germany or France during the 19th century, could rapidly reduce their Gerschenkronian backwardness by large investments and technological imitation. Further, long-term relationships, high average firm size and firm age, and little firm selection was supposed to be especially favorable to productivity growth. In such a situation, firms can best appropriate rents realized by their investments and imitation.

As economic wealth rose and markets became increasingly saturated with consumer goods, customers started demanding more individualized products, a process nicely illustrated by an example from the U.S. shirt production industry. Until the 1960s, men's shirts were a basic commodity and $70 \%$ of all shirts produced were white and of the same cut. By 1986, the market share of standardized white shirts had decreased to 20\% (Abernathy et al., 1999). Within a span of 20 years, uniformity was out, individuality in. This led to a change in production processes as individualized customer requirements could not be met with standardized mass production. Smaller batch numbers were produced and former economies 
of scale vanished. Manufacturers vertically disaggregated their production and started relying more on suppliers instead of producing everything themselves.

The 1970s are thought to be the best decade ever in heavyweight boxing-Muhammad Ali returned in 1970 from his forced retirement to take on Joe Frazier, who was world champion at the time. However, recent times have not been as favorable for industrial heavyweight champions. These days, to compete on the global technology frontier, further productivity growth can be realized only by pure innovation, not by imitation. In such a technologically advanced economy, the market selection process and firm turnover resulting from a process of creative destruction (Schumpeter, 1934) are the ultimate bases of innovation and, thus, productivity growth. Industries are now characterized by short-term relationships, younger firms, and less investment—changes modeled by Acemoglu, Aghion, and Zillibotti. (2002).

The remainder of the paper is organized as follows. Section 2 provides a brief overview of the theoretical arguments both in favor of and against large firms - the heavyweights - in an innovation-based economy. Section 3 reviews the literature on the relationship of firm size distribution and productivity growth. Section 4 is dedicated to an empirical analysis. Section 5 contains a summary and draws some conclusions.

\section{The Impact of Firm Size on Productivity Growth in an Innovation-Based Economy}

\subsection{Productive Innovation}

“Nowadays, nobody would question that a positive relationship exists between ... innovation on the one side and country-level performance ... on the other" (Brusoni, Cefis, and Orsenigo, 2007). However, there is disagreement over whether large firms are more or less innovative than their smaller counterparts. Could it be that large firms are simply innovative in a different way than that of their smaller counterparts? Basically, all arguments in favor and 
against large businesses being more innovative or innovative in a different way than their smaller counterparts refer to the ability of coping with uncertainty related to innovation and the internal (within an organization) and external (within the market) appropriability of postinnovative benefits.

Generally, a business's decision to innovate involves a high degree of uncertainty. Knight (1921, p. 231) remarks that such decisions "deal with situations which are far too unique, generally speaking, for any sort of statistical tabulation to have any value for guidance.” Against this background, Schumpeter (1942) basically argues that large businesses can better handle this uncertainty as they have more internal financial resources and more collateral assets with which to raise external funds and thus are more successful in dealing with the Knightian uncertainty related to innovation. By raising enough resources to establish large specialized research laboratories, large businesses manage, over time, to change innovation from being a sequence of fortuitous occurrences into a business-like activity that can be relied upon and is reasonably predictable (Baumol 2002, p. 55).

However, even if, in principle, large businesses can better handle this uncertainty, the organizational structure of large businesses is often assumed to be unsupportive of innovation. Acs et al. (1997) argue that an innovator in a large firm often has only limited property rights in his or her innovation. The new product or process generally belongs to the firm, not the employee who invented it. Thus, even in organizations with performance-oriented remuneration systems, the employee must share the returns from his or her innovative effort with many other employees, even if these others are not specifically associated with the innovation. Further, Bénabou and Tirole (2003) argue that rewards on "engagement" (innovative activity) have only a limited impact and possibly even a negative impact on "reengagement.” This second phenomenon may be the result of the employee's interest in 
protecting the cash flow generated by his or her old innovations (cf. Acs, Morck, and Yeung, 1999).

Furthermore, on the firm level, the appropriability of innovative rents may also depend on firm size and the firm's market share. Cohen and Klepper (1996a, b) present a model of firm size and the nature of innovation. They distinguish between product and process innovation. Process innovations increase the firm's price-cost margin by lowering the average cost of production. If the firm does not license process innovations, the only way the firm can benefit from the process innovations is in its own output. The higher the volume of production, the higher the total gross benefit of the process innovation. Hence, larger firms are able to derive a higher return from a process innovation than are smaller firms simply because the larger firms can spread this benefit over a greater volume. The same is not obvious for product innovation resulting in ground-breaking new products that create a completely new market. If there are no strong reasons for believing that the volume of sales on the new market is related to ex-ante size, there is obviously no reason why large businesses should spend relatively more time or money on product innovation than do their smaller counterparts.

In conclusion, from a theoretical perspective, a priori, there is no evidence on whether large firms are more innovative - and thus more prone to productivity growth - than their smaller counterparts. Nevertheless, they do perform relatively more process innovation than product innovation.

\subsection{Unproductive Innovation-Rent Seeking}

Baumol (2002) warns against assuming that all innovation is productive per se and thus enhances productivity growth. There may be activities that are highly innovative but nevertheless make little or no contribution to the real output of the economy. In this context, Baumol discusses innovative rent seeking. Rent seeking is any activity whose objective is the 
acquisition of economic rents that are available in the economy but that would be allocated to someone else in the absence of rent seeking. The most obvious example of this is when an incumbent firm finds a new way to persuade politicians or a regulatory agency to impose barriers to market entry so that the incumbent can skim additional rents.

Krueger (1974), Helpman and Grossman (2002), Rajan and Zingales (2003), and Morck, Wolfenzon, and Yeung (2005) emphasize that large incumbent firms are especially prone to invest in political rent seeking as a means of locking in the status quo. These firms are often assisted in this endeavor by politicians who also prefer the status quo, especially when seeking reelection. Roe (2003) argues that governments might lock in the status quo to please voters who prefer slow but smooth growth over faster but erratic growth. In this situation, one would not be too surprised to find a "save the lame ducks" campaign. "Lame ducks" are incumbent firms that were once at the front lines but have now fallen far behind. However, they are "too big to fail" (Vives, 2001) as their failure might have serious negative effects on employment in the short run. However, the "death” of a large business can have long-term effects on employment too, particularly when the labor market is inflexible and immobile. In this situation, state intervention can, at best, merely delay the inevitable, but politicians, who usually manage to think short term, especially those up for reelection, may wish to smooth out the process of decline and thus ease social tension.

This "save the lame duck at all costs" phenomenon is also found in the banking sector, as reported by Vives (2001). Politicians are apparently very taken with the idea that a national champion in the form of a bank must not be allowed to fail as the fallout would have such a negative impact on national industry. Particularly large banks are believed to be "too big to fail.” 
Thus, the direction in which innovations are finally canalized-productive or unproductiveis heavily dependent on a society's institutions. Morck, Wolfenzon, and Yeung (2005) go even further and argue that there might be a dynamic feedback loop between weak institutions and firm concentration. Weak institutions place sweeping corporate governance powers in the hands of a tiny elite group, who will, in turn, lobby on behalf of the weak institutions so as to preserve their concentrated control over the nation's large businesses.

\section{Survey of the Empirical Literature}

To date, there has been little empirical work analyzing the impact of firm size distribution on productivity growth. The four analyses on the industry or economy level that I am aware of come to different conclusions. The design and the main results of these four analyses are briefly summarized below.

Acs, Morck, and Yeung (1999) were the first to analyze the impact of firm size distribution in an industry on industry-level total factor productivity (TFP). They analyze 1991 crosssectional data for 450 4-digit-level U.S. manufacturing industries. They find that industries in which larger firms have a greater market share have a higher TFP. Market share is defined as employment share or establishment share. Their concentration on U.S. data may be helpful in pointing out how productivity growth and firm size distribution may be influenced by institutional environment (cf. Morck, Wolfenzon, and Yeung, 2005). To control for differences in industries, they add industry capital intensity and industry gross value added as controls. As TFP is calculated under the assumption of perfect competition and constant return to scale, they also control for possible "rents” in the TFP values by interacting the firm size distribution variables with indicators for competition intensity, such as firm turbulence or, again, capital intensity. However, they do not find “rents” in the TFP measure. 
Carree and Thurik (1998, 1999) analyze 13 manufacturing industries in 12 European countries for the period 1990 to 1995 . They regress growth of real value added from 1990 to 1993, to 1994, or to 1995 on large-firm presence in the year 1994. To control for country differences in the industry size distributions, they add GDP per capita index as an interaction term. Furthermore, they estimate the regression in differences from the overall industry means. Their results indicate that an industry with a low large-firm presence relative to the same industries in other countries has performed better, on average, in terms of growth of value added.

Pagano and Schivardi (2003) analyze the impact of firm size distribution in 22 industries (manufacturing, services, and construction) across eight European countries. Their analysis clearly shows that intra-industry size differences between countries are quite important. This finding underlines the importance of institutions for productivity and firm size distribution. Furthermore, they find positive effects of size in 1994 on per capita GDP growth between 1994 and 1998. However, this positive effect disappears when controlling for country-specific effects. As Pagano and Schivardi (2003) theorize that the positive effect of firm size distribution on growth is mainly driven indirectly via the positive effects large firms exert on innovation, they interact firm size distribution with input-oriented innovation indicators, such as the share of personnel employed in $R \& D, R \& D$ expenditure over investment, or $R \& D$ expenditure over value added in an industry. They find that size matters for growth only through its influence on innovation.

The most recent analysis, by Fogel, Morck, and Yeung (2006), differs from the ones discussed above in two ways. First, the analysis is at the country level, not at the industry level. Second, and more important, it takes a very long perspective by analyzing the effects of big business stability in 44 countries during the period 1975 to 1996 (data are available for the 
years 1975 and 1996) on economic growth (real per capita GDP growth or TFP growth) in the period 1990 to 2000. To control for differences in the countries under consideration, the authors add to their model the country's income level, physical capital stock, and human capital stock. Furthermore, they implement several controls for institutional differences in the countries. These controls range from the size of the government sector to indicators for the functioning of the financial system to the openness of a country. Their results suggest that countries with larger big business stability from 1975 to 1996 exhibited slower economic growth in the 1990s.

In summary, the results of these four studies suggest that the more "cross-section" in nature the data are (Acs et al., 1999), the more likely it is that the impact of large firms on economic growth will be found to be positive. In contrast, data of a more "time-series" nature (Fogel, Morck, and Yeung, 2006) lead to the result that the impact of large firms on economic growth is negative. This insight motivates the analyses presented below, which is based on an industry-level time-series dataset spanning 21 German manufacturing industries over the time period 1991 to 2004.

\section{Empirical Work}

\subsection{Data}

The data are at the industry level and cover 21 manufacturing industries over the timespan 1991 to 2004. The data are the result of a merger of the Ifo Industry Growth Accounting Database (cf. Roehn, Eicher, and Strobel, 2007), the Ifo Innovation Survey (cf. Penzkofer, 2004), and the establishment file of the German Social Security Statistics (cf. Brixy and Fritsch, 2004). Each of these datasets is a source of rich information on its own-the cumulative effect should be a much more vivid and accurate picture of German industry development. 
Information on productivity growth in terms of total factor productivity (TFP) growth is gleaned from the Ifo Industry Growth Accounting Database. By decomposing industry-level value-added (VA) growth, one can derive TFP growth as a residual:

$\Delta \ln V A_{i, t}=\bar{v}_{K, i, t} \Delta \ln K_{i, t}+\bar{v}_{L, i, t} \Delta \ln L_{i, t}+\Delta \ln T F P_{i, t}$

where $K_{i, t}$ and $L_{i, t}$ denote capital services and adjusted labor of industry $i$ in period $t$. The two-period average nominal input shares of capital and labor are $\bar{v}_{K, i, t}$ and $\bar{v}_{L, i, t}$, respectively. Capital services are flows of services by which each capital asset type contributes to the production process. The Ifo Industry Growth Accounting Database distinguishes 12 assets, which are derived by the perpetual inventory method. The 12 assets include three ICT assets (Computer and Office Equipment; Communication Equipment; Software), eight additional equipment assets (Metal Products; Machinery; Electrical Generation and Distribution; Instruments, Optics, and Watches; Furniture, Music, and Sports Equipment; Other Machines and Equipment; Automobiles; Other Vehicles), and investments in Buildings and Structures. Data on quality adjusted labor at the industry level are taken from the Groningen Industry Level Growth Accounting Database.

Industry-specific innovation activities of firms can be derived from the Ifo Innovation Survey. More than 1,000 surveyed firms report yearly whether or not they have introduced an innovation, i.e., product or process innovation. As the number of employees reported by the surveyed firms and the size distribution of firms in a respective industry are known, a projection of the survey data across the population is possible. The Ifo Innovation Survey thus makes it possible to derive indicators for the product and process innovation intensity in an industry. 
The German Social Insurance Statistics requires all employers to report information about every employee who is subject to obligatory social insurance. The information collected can be transformed into an establishment file that provides longitudinal information about the establishments and their employees. Thus, one can derive information on the establishment size distribution (in terms of employment) in an industry. Furthermore, as each establishment with at least one employee subject to social security has a permanent individual code number, it is possible to identify business start ups and closures. The appearance of a new code number can be interpreted as a startup; the disappearance of a code number can be interpreted as a closure. Businesses without employees are not included. The unit of measurement is the "establishment," not the company. The empirical data thus derived include two categories of entities: firm headquarters and subsidiaries. In the following analysis, the term business is used for both entities.

The industry-level variables are summarized in Table 1. Tables 2a through 2c display some descriptive statistics of the variables in use. 
Table 1: Industry-Level Variables

\begin{tabular}{|c|c|}
\hline Variable & $\begin{array}{l}\text { Definition } \\
\text { Source }\end{array}$ \\
\hline TFP growth & $\begin{array}{l}\text { Residual from the decomposition of yearly value-added growth } \\
\text { Ifo Industry Growth Accounting Database }\end{array}$ \\
\hline Value-added & $\begin{array}{l}\text { Additional value created in an industry } \\
\text { German Federal Statistical Office }\end{array}$ \\
\hline $\begin{array}{l}\text { Capacity utilization } \\
\text { index }\end{array}$ & $\begin{array}{l}\text { Relation of actual value-added to the trend component of value-added } \\
\text { (Hodrick-Prescott Filter with } \lambda=100 \text { ) }\end{array}$ \\
\hline $\begin{array}{l}\text { Share of large business } \\
\text { employment }\end{array}$ & $\begin{array}{l}\text { Number of employees in businesses with at least 1,000 employees over the } \\
\text { number of employees in all businesses in an industry } \\
\text { Establishment File of the German Social Insurance Statistics }\end{array}$ \\
\hline $\begin{array}{l}\text { Change of share of } \\
\text { large business } \\
\text { employment }\end{array}$ & $\begin{array}{l}\text { Yearly change of the share of large business employment } \\
\text { Establishment File of the German Social Insurance Statistics }\end{array}$ \\
\hline Capital intensity & $\begin{array}{l}\text { Capital stock over employees subject to social security } \\
\text { Ifo Industry Growth Accounting Database and German Social Insurance } \\
\text { Statistics }\end{array}$ \\
\hline Turbulence rate & $\begin{array}{l}\text { Sum of number of startups and closures over the number of existing businesses } \\
\text { Establishment File of the German Social Insurance Statistics }\end{array}$ \\
\hline $\begin{array}{l}\text { Share of product } \\
\text { innovators }\end{array}$ & $\begin{array}{l}\text { Number of product innovating businesses over number of all businesses in an } \\
\text { industry } \\
\text { Ifo Innovation Survey }\end{array}$ \\
\hline $\begin{array}{l}\text { Share of process } \\
\text { innovators }\end{array}$ & $\begin{array}{l}\text { Number of process innovating businesses over number of all businesses in an } \\
\text { industry } \\
\text { Ifo Innovation Survey }\end{array}$ \\
\hline
\end{tabular}


Table 2a: Descriptive Statistics, 1991-2004

\begin{tabular}{|c|c|c|c|c|c|c|c|c|c|c|c|c|}
\hline \multirow{2}{*}{ Industries } & \multicolumn{4}{|c|}{ TFP Growth (\%) } & \multicolumn{4}{|c|}{ Value Added (millions) } & \multicolumn{4}{|c|}{ Capacity Utilization Index } \\
\hline & Mean & Max & Min & Std.Dev. & Mean & Max & Min & Std.Dev. & Mean & Max & Min & Std.Dev. \\
\hline Food and Tobacco & -1.43 & 6.99 & -13.49 & 5.56 & 35.28 & 39.14 & 33.57 & 1.51 & 1.00 & 1.06 & 0.96 & 0.03 \\
\hline Textiles & 1.38 & 8.29 & -9.00 & 4.49 & 6.24 & 8.65 & 4.91 & 1.19 & 1.00 & 1.05 & 0.91 & 0.05 \\
\hline Apparel & 4.22 & 11.18 & 0.60 & 3.28 & 3.57 & 5.22 & 2.78 & 0.74 & 1.00 & 1.09 & 0.93 & 0.05 \\
\hline Leather & 2.47 & 16.80 & -4.86 & 5.96 & 1.23 & 1.72 & 0.96 & 0.25 & 1.00 & 1.09 & 0.92 & 0.05 \\
\hline Wood Products & 2.21 & 12.41 & -8.37 & 5.43 & 7.67 & 8.30 & 6.50 & 0.51 & 1.00 & 1.08 & 0.90 & 0.05 \\
\hline Paper, Pulp & 1.41 & 11.64 & -15.77 & 6.96 & 9.25 & 9.86 & 7.93 & 0.52 & 1.00 & 1.06 & 0.88 & 0.05 \\
\hline Publishing, Printing & -0.33 & 13.55 & -6.89 & 5.34 & 23.06 & 25.21 & 19.77 & 1.64 & 1.00 & 1.08 & 0.94 & 0.03 \\
\hline $\begin{array}{l}\text { Coke, Petroleum, Nuclear } \\
\text { Fuels }\end{array}$ & -16.44 & 115.87 & -240.39 & 92.78 & 10.97 & 51.41 & 1.51 & 12.57 & 1.12 & 2.39 & 0.20 & 0.69 \\
\hline Chemicals & 4.31 & 9.38 & -0.93 & 2.85 & 39.28 & 47.46 & 33.97 & 4.26 & 1.00 & 1.03 & 0.95 & 0.02 \\
\hline Rubber, Plastic & 1.67 & 5.71 & -2.93 & 2.55 & 18.83 & 21.66 & 16.70 & 1.52 & 1.00 & 1.03 & 0.97 & 0.02 \\
\hline $\begin{array}{l}\text { Non-Metallic Mineral } \\
\text { Products }\end{array}$ & 2.13 & 7.28 & -1.25 & 2.63 & 15.67 & 16.83 & 14.81 & 0.65 & 1.00 & 1.06 & 0.96 & 0.03 \\
\hline Basic Metals & 3.53 & 12.00 & -6.95 & 5.21 & 16.24 & 18.15 & 14.21 & 1.07 & 1.00 & 1.06 & 0.92 & 0.04 \\
\hline Fabricated Metal Products & 1.10 & 7.15 & -7.80 & 4.04 & 36.50 & 39.50 & 33.65 & 1.99 & 1.00 & 1.06 & 0.94 & 0.03 \\
\hline Machinery & 1.27 & 9.10 & -6.15 & 4.02 & 61.42 & 69.51 & 57.62 & 3.29 & 1.00 & 1.09 & 0.93 & 0.04 \\
\hline $\begin{array}{l}\text { Office Machinery and } \\
\text { Computers }\end{array}$ & 27.18 & 44.60 & 0.48 & 16.43 & 3.60 & 11.92 & 0.70 & 3.80 & 1.03 & 1.25 & 0.83 & 0.13 \\
\hline Electrical Apparatus n.e.c. & 1.29 & 7.92 & -15.92 & 7.27 & 30.39 & 33.31 & 27.98 & 1.96 & 1.00 & 1.11 & 0.93 & 0.05 \\
\hline $\begin{array}{l}\text { Radio, TV, and Comm. } \\
\text { Equipment }\end{array}$ & 6.67 & 25.65 & -15.63 & 14.00 & 10.55 & 18.26 & 6.81 & 3.05 & 0.99 & 1.24 & 0.72 & 0.16 \\
\hline $\begin{array}{l}\text { Instruments, Optics, and } \\
\text { Watches }\end{array}$ & 1.66 & 14.63 & -11.49 & 6.76 & 15.45 & 17.42 & 13.51 & 1.38 & 1.00 & 1.11 & 0.92 & 0.06 \\
\hline Motor Vehicles & 0.22 & 13.28 & -17.08 & 9.06 & 52.06 & 60.41 & 42.41 & 5.41 & 1.00 & 1.10 & 0.87 & 0.07 \\
\hline Other Transport Equipment & 4.05 & 22.48 & -13.84 & 11.81 & 7.05 & 9.69 & 4.23 & 1.89 & 1.00 & 1.24 & 0.72 & 0.15 \\
\hline $\begin{array}{l}\text { Furniture and Manufacturing } \\
\text { n.e.c }\end{array}$ & -1.17 & 4.61 & -8.51 & 3.88 & 12.29 & 15.58 & 9.17 & 1.97 & 1.00 & 1.07 & 0.93 & 0.05 \\
\hline All & 2.26 & 115.87 & -240.39 & 21.85 & 19.84 & 69.51 & 0.70 & 16.63 & 1.01 & 2.39 & 0.20 & 0.16 \\
\hline
\end{tabular}


Table 2b: Descriptive Statistics, 1991-2004

\begin{tabular}{|c|c|c|c|c|c|c|c|c|c|c|c|c|}
\hline \multirow[t]{2}{*}{ Industries } & \multicolumn{4}{|c|}{ Share of Large Business Employment (\%) } & \multicolumn{4}{|c|}{$\begin{array}{c}\text { Change of Share of Large Business } \\
\text { Employment (\%) }\end{array}$} & \multicolumn{4}{|c|}{ Capital Intensity (millions per employee) } \\
\hline & Mean & Max & Min & Std.Dev. & Mean & Max & Min & Std.Dev. & Mean & Max & Min & Std.Dev. \\
\hline Food and Tobacco & 5.21 & 6.78 & 4.16 & 1.10 & -0.13 & 0.93 & -1.02 & 0.44 & 0.09 & 0.10 & 0.06 & 0.01 \\
\hline Textiles & 6.52 & 10.55 & 4.59 & 2.10 & -0.29 & 1.18 & -2.48 & 0.89 & 0.09 & 0.12 & 0.04 & 0.02 \\
\hline Apparel & 2.60 & 4.98 & 0.00 & 1.50 & -0.23 & 1.29 & -1.60 & 0.95 & 0.03 & 0.06 & 0.01 & 0.01 \\
\hline Leather & 3.92 & 7.07 & 2.20 & 1.41 & 0.34 & 1.61 & -1.59 & 0.89 & 0.06 & 0.09 & 0.03 & 0.01 \\
\hline Wood Products & 5.67 & 8.43 & 3.40 & 1.70 & 0.39 & 1.96 & -3.32 & 1.46 & 0.05 & 0.07 & 0.03 & 0.01 \\
\hline Paper, Pulp & 11.54 & 14.40 & 7.17 & 2.32 & -0.54 & 0.78 & -1.40 & 0.61 & 0.12 & 0.14 & 0.08 & 0.02 \\
\hline Publishing, Printing & 9.07 & 12.96 & 6.27 & 1.80 & 0.22 & 1.76 & -1.52 & 1.06 & 0.07 & 0.09 & 0.04 & 0.02 \\
\hline $\begin{array}{l}\text { Coke, Petroleum, Nuclear } \\
\text { Fuels }\end{array}$ & 42.02 & 58.90 & 28.32 & 7.18 & 0.92 & 30.58 & -8.05 & 9.88 & 0.35 & 0.40 & 0.23 & 0.06 \\
\hline Chemicals & 49.61 & 61.17 & 44.00 & 5.68 & -0.45 & 7.77 & -3.75 & 3.05 & 0.14 & 0.18 & 0.09 & 0.03 \\
\hline Rubber, Plastic & 15.91 & 20.34 & 13.57 & 2.05 & -0.29 & 1.27 & -3.68 & 1.23 & 0.06 & 0.07 & 0.04 & 0.01 \\
\hline $\begin{array}{l}\text { Non-Metallic Mineral } \\
\text { Products }\end{array}$ & 14.96 & 24.29 & 8.67 & 5.12 & 0.53 & 5.40 & -5.45 & 3.22 & 0.10 & 0.13 & 0.06 & 0.02 \\
\hline Basic Metals & 21.11 & 30.15 & 17.66 & 3.91 & -0.36 & 4.45 & -3.72 & 2.17 & 0.09 & 0.10 & 0.06 & 0.01 \\
\hline Fabricated Metal Products & 10.09 & 15.25 & 7.54 & 2.23 & -0.37 & 2.85 & -2.44 & 1.21 & 0.05 & 0.06 & 0.03 & 0.01 \\
\hline Machinery & 20.98 & 28.65 & 18.54 & 2.89 & -0.18 & 5.22 & -4.23 & 2.15 & 0.05 & 0.06 & 0.03 & 0.01 \\
\hline $\begin{array}{l}\text { Office Machinery and } \\
\text { Computers }\end{array}$ & 30.96 & 44.11 & 22.45 & 6.52 & -0.46 & 7.81 & -16.39 & 7.05 & 0.15 & 0.18 & 0.09 & 0.03 \\
\hline Electrical Apparatus n.e.c. & 38.18 & 43.82 & 35.50 & 2.58 & 0.21 & 4.44 & -3.91 & 2.17 & 0.07 & 0.09 & 0.05 & 0.01 \\
\hline $\begin{array}{l}\text { Radio, TV, and Comm. } \\
\text { Equipment }\end{array}$ & 38.05 & 43.82 & 34.25 & 2.86 & 0.22 & 4.44 & -3.91 & 2.59 & 0.07 & 0.11 & 0.04 & 0.02 \\
\hline $\begin{array}{l}\text { Instruments, Optics, and } \\
\text { Watches }\end{array}$ & 13.24 & 17.98 & 11.07 & 2.53 & -0.33 & 1.45 & -3.07 & 1.14 & 0.03 & 0.04 & 0.02 & 0.00 \\
\hline Motor Vehicles & 49.95 & 53.46 & 48.47 & 1.59 & -0.32 & 0.94 & -2.23 & 0.97 & 0.10 & 0.12 & 0.08 & 0.01 \\
\hline Other Transport Equipment & 70.58 & 85.94 & 59.69 & 7.85 & 1.84 & 14.23 & -7.57 & 5.84 & 0.07 & 0.09 & 0.04 & 0.02 \\
\hline $\begin{array}{l}\text { Furniture and Manufacturing } \\
\text { n.e.c }\end{array}$ & 3.24 & 3.87 & 2.37 & 0.49 & 0.09 & 0.96 & -0.29 & 0.34 & 0.06 & 0.08 & 0.04 & 0.01 \\
\hline All & 22.07 & 85.94 & 0.00 & 19.06 & 0.04 & 30.58 & -16.39 & 3.26 & 0.09 & 0.40 & 0.01 & 0.07 \\
\hline
\end{tabular}


Table 2c: Descriptive Statistics, 1991-2004

\begin{tabular}{|c|c|c|c|c|c|c|c|c|c|c|c|c|}
\hline \multirow{2}{*}{ Industries } & \multicolumn{4}{|c|}{ Turbulence Rate (\%o) } & \multicolumn{4}{|c|}{ Share of Product Innovators (\%) } & \multicolumn{4}{|c|}{ Share of Process Innovators (\%) } \\
\hline & Mean & Max & Min & Std.Dev. & Mean & Max & Min & Std.Dev. & Mean & Max & Min & Std.Dev. \\
\hline Food and Tobacco & 107.69 & 117.72 & 100.14 & 6.18 & 33.83 & 47.83 & 26.37 & 6.13 & 19.07 & 27.40 & 8.89 & 5.48 \\
\hline Textiles & 153.47 & 175.92 & 110.23 & 16.86 & 34.74 & 46.15 & 23.53 & 7.14 & 18.88 & 33.82 & 14.00 & 5.01 \\
\hline Apparel & 225.91 & 265.39 & 186.37 & 19.46 & 27.08 & 38.71 & 6.90 & 9.33 & 14.88 & 31.82 & 0.00 & 9.35 \\
\hline Leather & 149.50 & 181.30 & 124.48 & 15.05 & 38.97 & 52.38 & 16.67 & 9.81 & 12.81 & 26.67 & 0.00 & 8.08 \\
\hline Wood Products & 120.99 & 151.06 & 84.66 & 24.89 & 13.97 & 28.33 & 5.66 & 5.82 & 15.35 & 25.00 & 9.09 & 4.70 \\
\hline Paper, Pulp & 114.03 & 137.36 & 91.46 & 14.64 & 19.26 & 25.69 & 10.75 & 4.37 & 17.36 & 22.47 & 8.60 & 3.93 \\
\hline Publishing, Printing & 148.24 & 171.91 & 122.96 & 16.83 & 12.39 & 19.35 & 5.62 & 4.51 & 19.72 & 27.42 & 11.96 & 4.71 \\
\hline $\begin{array}{l}\text { Coke, Petroleum, Nuclear } \\
\text { Fuels }\end{array}$ & 136.15 & 222.80 & 76.19 & 46.40 & 13.10 & 33.33 & 0.00 & 12.28 & 8.10 & 33.33 & 0.00 & 11.75 \\
\hline Chemicals & 124.27 & 141.30 & 102.30 & 12.59 & 51.25 & 64.71 & 30.00 & 8.25 & 34.99 & 45.28 & 24.00 & 7.10 \\
\hline Rubber, Plastic & 131.04 & 157.68 & 117.44 & 10.80 & 32.85 & 41.89 & 25.77 & 5.08 & 25.67 & 36.17 & 16.44 & 6.05 \\
\hline $\begin{array}{l}\text { Non-Metallic Mineral } \\
\text { Products }\end{array}$ & 142.67 & 165.31 & 128.69 & 10.26 & 21.67 & 27.66 & 13.33 & 4.30 & 19.58 & 25.86 & 16.16 & 3.15 \\
\hline Basic Metals & 128.52 & 164.09 & 111.49 & 14.84 & 21.73 & 48.28 & 8.70 & 9.31 & 23.16 & 41.38 & 8.70 & 9.31 \\
\hline Fabricated Metal Products & 161.63 & 175.68 & 138.07 & 8.67 & 20.20 & 28.28 & 15.04 & 3.93 & 20.08 & 25.52 & 13.04 & 3.78 \\
\hline Machinery & 128.19 & 138.39 & 111.74 & 6.61 & 37.99 & 42.11 & 33.23 & 3.19 & 24.33 & 31.32 & 19.34 & 3.28 \\
\hline $\begin{array}{l}\text { Office Machinery and } \\
\text { Computers }\end{array}$ & 212.99 & 252.44 & 186.30 & 21.57 & 10.00 & 40.00 & 0.00 & 16.49 & 6.19 & 33.33 & 0.00 & 12.67 \\
\hline Electrical Apparatus n.e.c. & 147.46 & 168.97 & 135.32 & 9.41 & 47.67 & 59.74 & 36.80 & 6.80 & 33.06 & 41.03 & 21.60 & 6.34 \\
\hline $\begin{array}{l}\text { Radio, TV, and Comm. } \\
\text { Equipment }\end{array}$ & 171.77 & 203.92 & 140.12 & 23.31 & 54.44 & 87.10 & 34.21 & 13.00 & 45.27 & 59.26 & 32.35 & 8.56 \\
\hline $\begin{array}{l}\text { Instruments, Optics, and } \\
\text { Watches }\end{array}$ & 121.76 & 155.31 & 103.44 & 13.45 & 48.72 & 63.16 & 43.59 & 5.75 & 25.72 & 29.82 & 19.51 & 3.04 \\
\hline Motor Vehicles & 124.96 & 140.54 & 105.53 & 11.86 & 51.67 & 69.57 & 33.33 & 10.74 & 38.09 & 65.22 & 14.29 & 16.82 \\
\hline Other Transport Equipment & 182.92 & 204.50 & 149.01 & 15.16 & 30.88 & 50.00 & 12.50 & 13.37 & 23.52 & 50.00 & 11.11 & 11.25 \\
\hline $\begin{array}{l}\text { Furniture and Manufacturing } \\
\text { n.e.c }\end{array}$ & 148.35 & 169.18 & 112.03 & 16.81 & 40.84 & 62.03 & 29.23 & 9.30 & 21.41 & 36.00 & 8.77 & 7.83 \\
\hline All & 146.79 & 265.39 & 76.19 & 34.66 & 31.58 & 87.10 & 0.00 & 16.29 & 22.25 & 65.22 & 0.00 & 12.12 \\
\hline
\end{tabular}




\subsection{The Impact of Large Businesses on Productivity Growth}

The final dataset consists of 19 manufacturing industries over a period of 14 years. As TFP growth in "Coke, Petroleum, Nuclear Fuels" and in "Office Machinery and Computers" follows a rather different pattern than that of the other industries (cf. Table 2a), these two industries are excluded from all regressions. Along the same lines, Acs, Morck, and Yeung (1999, p. 391) point out: “Our results would be ‘cleaner’ if computer related industries were taken out of our sample because these industries are known to have productivity trends very different from those of other industries.”

Beck and Katz (2004) call this special type of data, which has a finite and roughly equal number of units and number of observations per unit, time-series-cross-section (TSCS). Most recent literature has either concentrated on data where the number of units and the number of observations per unit are both very large or where the number of units is large and the number of observations per unit is small. The first type gave rise to the so-called panel co-integration models for heterogeneous panels (cf. Pesaran, Shin, and Smith, 1999). The latter type is discussed in the dynamic panel literature (cf. Arellano and Bond, 1991; Blundell and Bond, 1998). In the TSCS case, first preference is give to a fixed effects (FE) model with panel (White) corrected standard errors (cf. Williams, 2000). The FE model uses the changes in the variables over time to estimate the effects of the independent variables on the dependent variable.

In a first step, the relationship between TFP growth and large business presence is estimated, where large business presence is calculated as the share of employees in businesses with at least 1,000 employees over all employees in an industry and as the yearly change of the share of large business employment. A set of control variables is added, e.g., a full set of year dummies to capture time-series variation that is common to all industries, an industry-specific 
capacity utilization index to control for industry-specific business cycles, or a lagged dependent variable to control for serial correlation because it often takes time to adopt productivity improving technologies.

Table 3 displays the results of the first step. Except for Regression IV, all regressions are FE models with a full set of year dummies and panel corrected standard errors, as tests for the equality of the residuals' variances by industry clearly suggest that there is a remaining crosssectional heteroscedasticity by industry. Regression IV is the only between estimation, i.e., a regression run on the means (over time) of the variables. It is the only regression that results in a significantly positive impact of large business presence on TFP growth.

Table 3: Regressions on Total Factor Productivity

\begin{tabular}{|c|c|c|c|c|}
\hline Variable & I & II & III & IV \\
\hline Lagged share of large & $-0.2892 *$ & $-0.3065 *$ & -0.1589 & $0.0436 *$ \\
\hline business employment & $(0.1624)$ & $(0.1712)$ & $(0.1475)$ & $(0.0228)$ \\
\hline Change of share of large & $-0.5858 * *$ & $-0.7458 * *$ & $-0.8845^{* * *}$ & - \\
\hline business employment & $(0.2931)$ & $(0.3604)$ & $(0.3100)$ & \\
\hline $\mathrm{N}$ & 247 & 228 & 247 & 19 \\
\hline Adj. $\mathrm{R}^{2}$ & 0.08 & 0.08 & 0.30 & 0.13 \\
\hline Industry fixed effects & Yes & Yes & Yes & - \\
\hline Period fixed effects & Yes & Yes & Yes & \\
\hline White (diagonal) & Yes & Yes & Yes & $\overline{\text { Yes }}$ \\
\hline \multirow{3}{*}{ Controls } & & Laơod & Canacity & \\
\hline & & Denendent & Utilization & \\
\hline & & Variable & Index $* * *$ & \\
\hline
\end{tabular}

I-III cross-section-time-series; IV pure cross-section, between estimates.

*** significant at the $1 \%$ level; ** significant at the $5 \%$ level; * significant at the $10 \%$ level.

Standard errors in parentheses.

Regression I is the basic model. The share of large business employment and its change both have a significantly negative impact on TFP growth. An inspection of the serial correlation between the lagged residuals shows that even in the basic model there is no remaining partial correlation. Hence, there is no obvious necessity to add a dependent lagged variable to reduce serial correlation. Inclusion of the lagged dependent variable-Regression II-does not change the basic results dramatically. Furthermore, the slope coefficient of the lagged dependent variable is not significantly different from zero. Basically, one should not 
overvalue the results of the FE regressions with the inclusion of a lagged dependent variable. It is well known that the inclusion of a lagged dependent variable in an FE model may cause problems because of its correlation with the fixed effects. In this case, Nickell (1981) shows that the FE estimator is biased of order $1 / T$. However, since the time series examined in this paper is relatively long, the fixed-effects estimator is more likely to be consistent.

Inclusion of the capacity utilization index in Regression III to control for industry-specific business cycles changes the results in that the coefficient of the share of large business employment becomes insignificant, whereas the coefficient of the change of large businesses employment share stays significantly negative. The slope coefficient of the capacity utilization index is significantly different from zero.

Regressions were also run with other limit values for the share of large business employment. In the case of smaller values (e.g., businesses with at least 500 employees), the results were ambiguous. In the case of larger values (e.g., businesses with at least 5,000 employees-the “real” heavyweights), there was an increasing number of industries with a zero share of large business employment.

Even in the case of a negative average relationship between large business presence and TFP growth, there might be some industries where this relationship is positive. To allow for heterogeneity in the relationship between TFP growth and large business presence over industry, in a further step the large business variables are interacted with (time-invariant) industry characteristics.

The first candidates for interaction are capital intensity and business turbulence rate. These variables might serve as proxies for competition intensity in the industry and, therefore, control for the possibility that TFP growth contains "rents." Acs, Morck, and Yeung (1999) argue that TFP growth in industries with more market power may register higher TFP growth 
not because they experience higher TFP growth, but because the TFP calculation may include rents due to the market power of incumbent firms in the industry. This measurement error might than be captured by the large businesses slope coefficient in the basic model. If "rent" is the only explanation for the impact of large business presence on TFP growth, the large businesses slope coefficient should become zero while the slope coefficient of the interaction between large business presence and competition intensity should be significantly different from zero. Capital intensity and business turbulence rate enter the model as industry-specific means over the entire time period. They therefore represent time-invariant industry characteristics.

Table 4 displays the results of regressions expanded by the interaction of large business presence with proxies for competition intensity. In all specifications, the slope coefficient of the share of large business employment is significantly different from zero. Calculating the point estimates of the effect of large businesses employment share on TFP growth for each industry depending on the industry-specific value of capital intensity or the value of the turbulence rate, respectively, one sees that in industries with high values of capital intensity (at least $€ 0.12$ million per employee in the specification without controls) or low values for the turbulence rate (maximum 132 net entries per 1,000 incumbent businesses in the specification without controls), the industry-specific effect of the share of large business employment on TFP growth is positive (e.g., Chemicals or Paper and Pulp). The point estimates are the sum of the slope coefficients of the share of large business employment and the slope coefficients of the respective interaction term multiplied by the value of capital intensity or turbulence rate in an industry. However, it turns out that neither of the positive estimates is significantly different from zero assuming a 5\% significance level. This clearly suggests that the argument that the TFP measure contains "rents" cannot be supported by empirical evidence. 
Table 4: Regressions on Total Factor Productivity

\begin{tabular}{|c|c|c|c|c|c|c|}
\hline Variable & $\mathrm{I}$ & II & III & IV & $\mathrm{V}$ & VI \\
\hline Lagged share of large business employment & $\begin{array}{l}-1.0161^{* * *} \\
(0.3758)\end{array}$ & $\begin{array}{l}-1.2938^{* * *} \\
(0.4251)\end{array}$ & $\begin{array}{c}-0.6967 * * \\
(0.3597)\end{array}$ & $\begin{array}{l}1.7473^{* *} \\
(0.7871)\end{array}$ & $\begin{array}{l}1.8978 * * \\
(0.8316)\end{array}$ & $\begin{array}{l}1.5819 * * \\
(0.8005)\end{array}$ \\
\hline $\begin{array}{l}\text { Change of share of large business } \\
\text { employment }\end{array}$ & $\begin{array}{c}-1.1932 * * \\
(0.6228)\end{array}$ & $\begin{array}{l}-2.1233^{* *} \\
(0.9395)\end{array}$ & $\begin{array}{l}-2.1264^{* * *} \\
(0.6315)\end{array}$ & $\begin{array}{c}0.5183 \\
(1.0933)\end{array}$ & $\begin{array}{c}0.5542 \\
(1.7469)\end{array}$ & $\begin{array}{l}1.8805^{*} \\
(1.0523)\end{array}$ \\
\hline $\begin{array}{l}\text { Lagged share of large business employment } \\
\text { * Capital intensity }\end{array}$ & $\begin{array}{l}8.2147 * * * \\
(3.1992)\end{array}$ & $\begin{array}{l}11.4838 * * * \\
(3.7651)\end{array}$ & $\begin{array}{c}6.2080^{* *} \\
(3.1917)\end{array}$ & - & 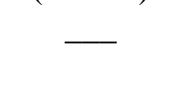 & + \\
\hline $\begin{array}{l}\text { Change of share of large business } \\
\text { employment * Capital intensity }\end{array}$ & $\begin{array}{c}7.0628 \\
(5.7811)\end{array}$ & $\begin{array}{l}17.7083^{*} \\
(9.9899)\end{array}$ & $\begin{array}{l}15.0012^{* * *} \\
(5.6597)\end{array}$ & - & 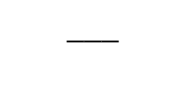 & - \\
\hline $\begin{array}{l}\text { Lagged share of large business employment } \\
\text { * Turbulence rate }\end{array}$ & - & 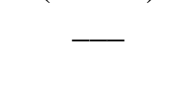 & - & $\begin{array}{c}-0.0133 * * * \\
(0.0053)\end{array}$ & $\begin{array}{c}-0.0143^{* * *} \\
(0.0056)\end{array}$ & $\begin{array}{c}-0.0113 * * \\
(0.0055)\end{array}$ \\
\hline $\begin{array}{l}\text { Change of share of large business } \\
\text { employment * Turbulence rate }\end{array}$ & $\underline{-}$ & 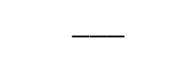 & $\underline{-}$ & $\begin{array}{l}-0.0069 \\
(0.0072)\end{array}$ & $\begin{array}{l}-0.0076 \\
(0.0113)\end{array}$ & $\begin{array}{c}-0.0170 * * \\
(0.0070)\end{array}$ \\
\hline $\mathrm{N}$ & 247 & 228 & 247 & 247 & 228 & 247 \\
\hline Adj. $R^{2}$ & 0.09 & 0.09 & 0.32 & 0.10 & 0.10 & 0.33 \\
\hline Industry fixed effects & Yes & Yes & Yes & Yes & Yes & Yes \\
\hline Period fixed effects & Yes & Yes & Yes & Yes & Yes & Yes \\
\hline White (diagonal) corrected standard errors & Yes & Yes & Yes & Yes & Yes & Yes \\
\hline Controls & 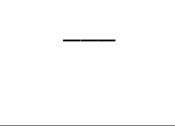 & $\begin{array}{l}\text { Lagged } \\
\text { Dependent } \\
\text { Variable }\end{array}$ & $\begin{array}{c}\text { Capacity } \\
\text { Utilization*** }\end{array}$ & 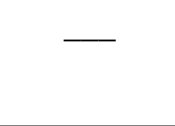 & $\begin{array}{c}\text { Lagged } \\
\text { Dependent } \\
\text { Variable }\end{array}$ & $\begin{array}{c}\text { Capacity } \\
\text { Utilization*** }\end{array}$ \\
\hline
\end{tabular}

*** significant at the $1 \%$ level; ** significant at the $5 \%$ level; * significant at the $10 \%$ level.

Standard errors in parentheses. 
To test whether large business presence supports TFP growth in innovation-intensive industries, the large business variable is interacted with innovation intensity. To allow for different types of innovation, large business presence is either interacted with process innovation intensity or product innovation intensity. Process innovation intensity and product innovation intensity are calculated as industry-specific means over the entire period. Table 5 displays the results of these regressions. In all specifications except those including the capacity utilization index as control, the slope coefficient of large business presence remains significantly negative. The slope coefficients of the interaction of large business presence and share of product innovators or share of process innovators are generally positive. The coefficients for the interaction with share of process innovators are generally higher than the coefficients for the interaction with share of product innovators. However, these coefficients sometimes turn out to be not significantly different from zero. Calculating the industryspecific point estimates for the effect of large business presence, there are some innovationintensive industries (at least 51 product innovators or 34 process innovators per 100 firms in the basic specification without controls) where this effect is positive (e.g., Chemicals, Motor Vehicles, and Radio, TV, and Comm. Equipment). Interestingly, Radio, TV, and Comm. Equipment is an industry with a high degree of market selection (this industry has one of the largest turbulence rates in the sample), whereas Chemicals and Motor Vehicles are both industries characterized by very little selection. It might be stiff international competition between incumbents with large research laboratories that drives innovation in the latter two industries. However, neither of these positive point estimates is significantly different from zero assuming a 5\% significance level. 
Table 5: Regressions on Total Factor Productivity

\begin{tabular}{|c|c|c|c|c|c|c|}
\hline Variable & I & II & III & IV & V & VI \\
\hline Lagged share of large business employment & $\begin{array}{l}-0.7361^{*} \\
(0.4234)\end{array}$ & $\begin{array}{c}-1.1035^{* *} \\
(0.5145)\end{array}$ & $\begin{array}{c}0.1864 \\
(0.3978)\end{array}$ & $\begin{array}{l}-1.0984^{*} \\
(0.6339)\end{array}$ & $\begin{array}{c}-1.5251^{* *} \\
(0.7821)\end{array}$ & $\begin{array}{c}0.1936 \\
(0.5503)\end{array}$ \\
\hline $\begin{array}{l}\text { Change of share of large business } \\
\text { employment }\end{array}$ & $\begin{array}{c}-2.1153^{* * *} \\
(0.7281)\end{array}$ & $\begin{array}{c}-3.2261 * * * \\
(1.0743)\end{array}$ & $\begin{array}{l}-1.7712^{* * *} \\
(0.7149)\end{array}$ & $\begin{array}{c}-2.5065 * * * \\
(0.9263)\end{array}$ & $\begin{array}{c}-3.6447 * * * \\
(1.3429)\end{array}$ & $\begin{array}{c}-2.0683^{* *} \\
(0.9492)\end{array}$ \\
\hline $\begin{array}{l}\text { Lagged share of large business employment } \\
* \text { Share of product innovators }\end{array}$ & $\begin{array}{c}0.0142 \\
(0.0119)\end{array}$ & $\begin{array}{l}0.0266^{*} \\
(0.0153)\end{array}$ & $\begin{array}{l}-0.0092 \\
(0.0106)\end{array}$ & 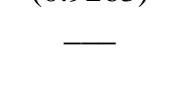 & 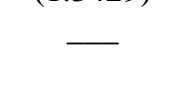 & 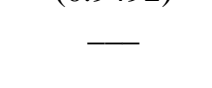 \\
\hline $\begin{array}{l}\text { Change of share of large business } \\
\text { employment * Share of product innovators }\end{array}$ & $\begin{array}{l}0.0459 * * \\
(0.0206)\end{array}$ & $\begin{array}{l}0.0785 * * \\
(0.0339)\end{array}$ & $\begin{array}{c}0.0263 \\
(0.0190)\end{array}$ & - & - & - \\
\hline $\begin{array}{l}\text { Lagged share of large business employment } \\
* \text { Share of process innovators }\end{array}$ & 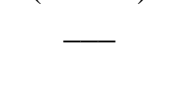 & 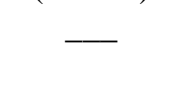 & - & $\begin{array}{c}0.0331 \\
(0.0250)\end{array}$ & $\begin{array}{l}0.0517 * \\
(0.0315)\end{array}$ & $\begin{array}{l}-0.0129 \\
(0.0207)\end{array}$ \\
\hline $\begin{array}{l}\text { Change of share of large business } \\
\text { employment } * \text { Share of process innovators }\end{array}$ & 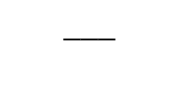 & - & - & $\begin{array}{c}0.0756 * * \\
(0.0366)\end{array}$ & $\begin{array}{l}0.1194 * * \\
(0.0569)\end{array}$ & $\begin{array}{c}0.0456 \\
(0.0362)\end{array}$ \\
\hline $\mathrm{N}$ & 247 & 228 & 247 & 247 & 228 & 247 \\
\hline Adj. $\mathrm{R}^{2}$ & 0.10 & 0.12 & 0.31 & 0.11 & 0.12 & 0.32 \\
\hline Industry fixed effects & Yes & Yes & Yes & Yes & Yes & Yes \\
\hline Period fixed effects & Yes & Yes & Yes & Yes & Yes & Yes \\
\hline White (diagonal) corrected standard errors & Yes & Yes & Yes & Yes & Yes & Yes \\
\hline Controls & - & $\begin{array}{l}\text { Lagged } \\
\text { Dependent } \\
\text { Variable }\end{array}$ & $\begin{array}{c}\text { Capacity } \\
\text { Utilization*** }\end{array}$ & - & $\begin{array}{c}\text { Lagged } \\
\text { Dependent } \\
\text { Variable }\end{array}$ & $\begin{array}{c}\text { Capacity } \\
\text { Utilization*** }\end{array}$ \\
\hline
\end{tabular}

*** significant at the $1 \%$ level; ** significant at the $5 \%$ level; * significant at the $10 \%$ level.

Standard errors in parentheses. 


\section{Summary and Conclusions}

The results suggest that in industries with high competition and/or market selection, there is a positive effect of large business on productivity growth in the presence of innovation. This is especially true for process innovation. The latter result is in line with Cohen and Klepper's (1996a, b) model of firm size and the nature of innovation. However, this positive effect is overshadowed by a negative impact of large business presence on productivity growth. Accompanying the fact that large firms' organizational structures often are not supportive of innovation, is the bitter after-taste of large businesses in their role as successful lobbyists. Wealthy families, elite cadres of professional managers, or bureaucrats (in the case of stateowned firms) often have control over large businesses and are well connected to politics. They thus have the power to lobby on behalf of weak institutions so as to preserve their concentrated control over the nation's large businesses. This concentrated control over large businesses may lead to various market power distortions, particularly in regard to innovation. Morck, Wolfenzon, and Yeung (2005) call this state of affairs “oligarchic capitalism,” and state that when this situation exists, economic policy is no longer available as a cure for economic ills. The only way to break this stranglehold is to set up strong institutions that will prevent rent seeking. This is not a new conclusion—nor even a new solution to it-but as long as there is such a paucity of theoretical and empirical work aimed at the design of strong institutions, it is not a conclusion that can realistically be rewritten in a more hopeful form. Therefore, research and discussion on these issues should be intensified-theoretically and empirically_and the issue should be kept alive in political debate.

\section{Acknowledgments}

The research is based on the project "How to Construct Europe" funded by the German Leibniz Association. I am indebted to the participants of workshops at the Entrepreneurship, 
Growth, and Public Policy Group at the Max Plank Institute for Economics in Jena, Germany, and at the Human Capital and Innovation Group at the Ifo Institute for Economic Research in Munich, Germany, for comments on an earlier version of this paper. 


\section{References}

Abernathy, F., J. Dunlop, J. Hammond, and D. Weil (1999). A Stitch in Time. New York: Oxford University Press.

Acemoglu, D., P. Aghion, and F. Zilibotti (2002). Distance to Frontier, Selection, and Economic Growth. NBER Working Paper 9066.

Acs, Z., R. Morck, M. Shaver, and B. Yeung (1997). “The Internationalization of Small and Medium-Sized Enterprises: A Policy Perspective.” Small Business Economics 9, 720.

Acs, Z., R. Morck, and B. Yeung (1999). Productivity Growth and Firm Size Distribution. In Acs, Z., B. Carlsson, and C. Karlsson (eds.), Entrepreneurship, Small and Medium Enterprises and the Macroeconomy. Cambridge: Cambridge University Press.

Arellano, M. and S. Bond (1991). "Some Tests of Specification for Panel Data: Monte Carlo Evidence and an Application to Employment Equations.” Review of Economic Studies 58, 277-297.

Baumol, W. (2002). The Free-Market Innovation Machine. Princeton and Oxford: Princeton University Press.

Beck, N. and J. Katz (2004). Time Series Cross Section Issues: Dynamics, 2004. Mimeo, New York University.

Bénabou, R. and J. Tirole (2003). “Intrinsic and Extrinsic Motivation.” Review of Economic Studies 70, 489-520.

Blundell, R. and S. Bond (1998). "Initial Conditions and Moment Restrictions in Dynamic Panel Data Models.” Journal of Econometrics 87, 115-143. 
Brixy, U. and M. Fritsch (2004). “The Establishment File of the German Social Insurance Statistics.” Schmollers Jahrbuch/Journal of Applied Social Science Studies 124, 183190.

Brusoni, S., E. Cefis, and L. Orsenigo (2007). Innovate or Die? A Critical Review of the Literature on Innovation and Performance. In Cassis, Y. and A. Colli (eds.), Business Performance in the XX Century: A Comparative Perspective. Cambridge: Cambridge University Press.

Carree, M. and A. R. Thurik (1998). "Small Firms and Economic Growth in Europe.” Atlantic Economic Journal 26, 137-146.

Carree, M. and A. R. Thurik. (1999). Industrial Structure and Economic Growth. In Audretsch, D. B. and A. R. Thurik (eds.), Innovation, Industry Evolution, and Employment. Cambridge: Cambridge University Press.

Cohen, W. and S. Klepper (1996a). “A Reprise of Size and R\&D.” Economic Journal 106, 925-951.

Cohen, W. and S. Klepper (1996b). "Firm Size and the Nature of Innovation Within Industries: The Case of Process and Product R\&D.” Review of Economics and Statistics 78, 232-243.

Fogel, K., R. Morck, and B. Yeung (2006). Big Business Stability and Economic Growth: Is What’s Good for General Motors Good for America? NBER Working Paper 12394.

Gerschenkron, A. (1962). Economic Bachwardness in Historical Perspective. Cambridge: Harvard University Press.

Heblich, S. (2007). Eigenverantwortliche Individuen und Pro-Aktive Unternehmen [SelfReliant Individuals and Pro-Active Companies]. Discussion Paper V-48-07, University of Passau. 
Helpman, E. and G. Grossman (2002). Interest Groups and Trade Policy. Princeton: Princeton University Press.

Knight, F. (1921). Risk, Uncertainty, and Profit. Boston: Hart, Schaffner \& Marx.

Krueger, A. (1974). “The Political Economy of the Rent-Seeking Society.” American Economic Review 64, 291-303.

Morck, R., D. Wolfenzon, and B. Yeung (2005). “Corporate Governance, Economic Entrenchment and Growth.” Journal of Economic Literature 43, 657-720.

Nickell, S. (1981). “Biases in Dynamic Models with Fixed Effects.” Econometrica 49, 1399_ 1416.

Pagano, P. and F. Schivardi (2003). “Firm Size Distribution and Growth.” Scandinavian Journal of Economics 105, 255-274.

Penzkofer, H. (2004). Innovationstest (Ifo Innovation Survey). In Goldrian, G. (ed.), Handbuch der umfragebasierten Konjunkturforschung, ifo Beiträge zur Wirtschaftsforschung 15.

Pesaran, M. H., Y. Shin, and R. Smith (1999). "Pooled Mean Group Estimation of Dynamic Heterogeneous Panels.” Journal of the American Statistical Association 94, 621-634.

Rajan, R. and L. Zingales (2003). “The Great Reversals: the Politics of Financial Development in the Twentieth Century.” Journal of Financial Economics 69, 5-50.

Roe, M. (2003). Political Determinants of Corporate Governance. Oxford: Oxford University Press.

Roehn, O., T. Eicher, and T. Strobel (2007). The Ifo Industry Growth Accounting Database. CESifo Working Paper 1915,

Schumpeter, J. A. (1934). The Theory of Economic Development. Cambridge: Harvard University Press. 
Schumpeter, J. A. (1942). Capitalism, Socialism and Democracy. New York: Harper \& Brothers.

Vives, X. (2001). “Restructuring Financial Regulation in the European Monetary Union.” Journal of Financial Services Research 19, 57-82.

Williams, R. L. (2000). “A Note on Robust Variance Estimation for Cluster Correlated Data.” Biometrics 56, 645-646. 


\section{CESifo Working Paper Series}

for full list see www.cesifo-group.org/wp

(address: Poschingerstr. 5, 81679 Munich, Germany, office@cesifo.de)

2072 Marco Runkel and Guttorm Schjelderup, The Choice of Apportionment Factors under Formula Apportionment, August 2007

2073 Jay Pil Choi, Tying in Two-Sided Markets with Multi-Homing, August 2007

2074 Marcella Nicolini, Institutions and Offshoring Decision, August 2007

2075 Rainer Niemann, The Impact of Tax Uncertainty on Irreversible Investment, August 2007

2076 Nikitas Konstantinidis, Gradualism and Uncertainty in International Union Formation, August 2007

2077 Maria Bas and Ivan Ledezma, Market Access and the Evolution of within Plant Productivity in Chile, August 2007

2078 Friedrich Breyer and Stefan Hupfeld, On the Fairness of Early Retirement Provisions, August 2007

2079 Scott Alan Carson, Black and White Labor Market Outcomes in the $19^{\text {th }}$ Century American South, August 2007

2080 Christian Bauer, Paul De Grauwe and Stefan Reitz, Exchange Rates Dynamics in a Target Zone - A Heterogeneous Expectations Approach, August 2007

2081 Ana Rute Cardoso, Miguel Portela, Carla Sá and Fernando Alexandre, Demand for Higher Education Programs: The Impact of the Bologna Process, August 2007

2082 Christian Hopp and Axel Dreher, Do Differences in Institutional and Legal Environments Explain Cross-Country Variations in IPO Underpricing?, August 2007

2083 Hans-Werner Sinn, Pareto Optimality in the Extraction of Fossil Fuels and the Greenhouse Effect: A Note, August 2007

2084 Robert Fenge, Maximilian von Ehrlich and Matthias Wrede, Fiscal Competition, Convergence and Agglomeration, August 2007

2085 Volker Nitsch, Die Another Day: Duration in German Import Trade, August 2007

2086 Kam Ki Tang and Jie Zhang, Morbidity, Mortality, Health Expenditures and Annuitization, August 2007

2087 Hans-Werner Sinn, Public Policies against Global Warming, August 2007 
2088 Arti Grover, International Outsourcing and the Supply Side Productivity Determinants, September 2007

2089 M. Alejandra Cattaneo and Stefan C. Wolter, Are the Elderly a Threat to Educational Expenditures?, September 2007

2090 Ted Bergstrom, Rod Garratt and Damien Sheehan-Connor, One Chance in a Million: Altruism and the Bone Marrow Registry, September 2007

2091 Geraldo Cerqueiro, Hans Degryse and Steven Ongena, Rules versus Discretion in Loan Rate Setting, September 2007

2092 Henrik Jacobsen Kleven, Claus Thustrup Kreiner and Emmanuel Saez, The Optimal Income Taxation of Couples as a Multi-Dimensional Screening Problem, September 2007

2093 Michael Rauber and Heinrich W. Ursprung, Life Cycle and Cohort Productivity in Economic Research: The Case of Germany, September 2007

2094 David B. Audretsch, Oliver Falck and Stephan Heblich, It's All in Marshall: The Impact of External Economies on Regional Dynamics, September 2007

2095 Michael Binder and Christian J. Offermanns, International Investment Positions and Exchange Rate Dynamics: A Dynamic Panel Analysis, September 2007

2096 Louis N. Christofides and Amy Chen Peng, Real Wage Chronologies, September 2007

2097 Martin Kolmar and Andreas Wagener, Tax Competition with Formula Apportionment: The Interaction between Tax Base and Sharing Mechanism, September 2007

2098 Daniela Treutlein, What actually Happens to EU Directives in the Member States? - A Cross-Country Cross-Sector View on National Transposition Instruments, September 2007

2099 Emmanuel C. Mamatzakis, An Analysis of the Impact of Public Infrastructure on Productivity Performance of Mexican Industry, September 2007

2100 Gunther Schnabl and Andreas Hoffmann, Monetary Policy, Vagabonding Liquidity and Bursting Bubbles in New and Emerging Markets - An Overinvestment View, September 2007

2101 Panu Poutvaara, The Expansion of Higher Education and Time-Consistent Taxation, September 2007

2102 Marko Koethenbuerger and Ben Lockwood, Does Tax Competition Really Promote Growth?, September 2007

2103 M. Hashem Pesaran and Elisa Tosetti, Large Panels with Common Factors and Spatial Correlations, September 2007 
2104 Laszlo Goerke and Marco Runkel, Tax Evasion and Competition, September 2007

2105 Scott Alan Carson, Slave Prices, Geography and Insolation in $19^{\text {th }}$ Century AfricanAmerican Stature, September 2007

2106 Wolfram F. Richter, Efficient Tax Policy Ranks Education Higher than Saving, October 2007

2107 Jarko Fidrmuc and Roman Horváth, Volatility of Exchange Rates in Selected New EU Members: Evidence from Daily Data, October 2007

2108 Torben M. Andersen and Michael Svarer, Flexicurity - Labour Market Performance in Denmark, October 2007

2109 Jonathan P. Thomas and Tim Worrall, Limited Commitment Models of the Labor Market, October 2007

2110 Carlos Pestana Barros, Guglielmo Maria Caporale and Luis A. Gil-Alana, Identification of Segments of European Banks with a Latent Class Frontier Model, October 2007

2111 Felicitas Nowak-Lehmann D., Sebastian Vollmer and Immaculada Martínez-Zarzoso, Competitiveness - A Comparison of China and Mexico, October 2007

2112 Mark Mink, Jan P.A.M. Jacobs and Jakob de Haan, Measuring Synchronicity and Comovement of Business Cycles with an Application to the Euro Area, October 2007

2113 Ossip Hühnerbein and Tobias Seidel, Intra-regional Tax Competition and Economic Geography, October 2007

2114 Christian Keuschnigg, Exports, Foreign Direct Investment and the Costs of Corporate Taxation, October 2007

2115 Werner Bönte, Oliver Falck and Stephan Heblich, Demography and Innovative Entrepreneurship, October 2007

2116 Katrin Assenmacher-Wesche and M. Hashem Pesaran, Assessing Forecast Uncertainties in a VECX Model for Switzerland: An Exercise in Forecast Combination across Models and Observation Windows, October 2007

2117 Ben Lockwood, Voting, Lobbying, and the Decentralization Theorem, October 2007

2118 Andrea Ichino, Guido Schwerdt, Rudolf Winter-Ebmer and Josef Zweimüller, Too Old to Work, too Young to Retire?, October 2007

2119 Wolfgang Eggert, Tim Krieger and Volker Meier, Education, Unemployment and Migration, October 2007

2120 Stefan Napel and Mika Widgrén, The European Commission - Appointment, Preferences, and Institutional Relations, October 2007 
2121 Bertil Holmlund and Martin Söderström, Estimating Income Responses to Tax Changes: A Dynamic Panel Data Approach, October 2007

2122 Doina Maria Radulescu, From Separate Accounting to Formula Apportionment: Analysis in a Dynamic Framework, October 2007

2123 Jelle Brouwer, Richard Paap and Jean-Marie Viaene, The Trade and FDI Effects of EMU Enlargement, October 2007

2124 Kurt R. Brekke, Luigi Siciliani and Odd Rune Straume, Competition and Waiting Times in Hospital Markets, October 2007

2125 Alexis Direr, Flexible Life Annuities, October 2007

2126 Johannes Becker and Clemens Fuest, Quality versus Quantity - The Composition Effect of Corporate Taxation on Foreign Direct Investment, October 2007

2127 Balázs Égert, Real Convergence, Price Level Convergence and Inflation Differentials in Europe, October 2007

2128 Marko Koethenbuerger, Revisiting the "Decentralization Theorem” - On the Role of Externalities, October 2007

2129 Axel Dreher, Silvia Marchesi and James Raymond Vreeland, The Politics of IMF Forecasts, October 2007

2130 Andreas Knabe and Ronnie Schöb, Subsidizing Extra Jobs: Promoting Employment by Taming the Unions, October 2007

2131 Michel Beine and Bertrand Candelon, Liberalization and Stock Market Co-Movement between Emerging Economies, October 2007

2132 Dieter M. Urban, FDI Technology Spillovers and Wages, October 2007

2133 Valentina Bosetti, Carlo Carraro, Emanuele Massetti and Massimo Tavoni, Optimal Energy Investment and R\&D Strategies to Stabilise Greenhouse Gas Atmospheric Concentrations, October 2007

2134 David-Jan Jansen and Jakob de Haan, The Importance of Being Vigilant: Has ECB Communication Influenced Euro Area Inflation Expectations?, October 2007

2135 Oliver Falck, Heavyweights - The Impact of Large Businesses on Productivity Growth, October 2007 